\title{
Análise exegética de Ecl 12,1-8: Velhice e morte na ótica de Qohelet
}

\author{
Orientador: Leonardo Agostini Fernandes \\ Mestrando: Bruno José dos Santos \\ Área de Concentração: Teologia Bíblica
}

Linha de Pesquisa: Análise e Interpretação de Textos do Antigo e Novo Testamento

Projeto de Pesquisa: Interpretação e leitura canônica de textos proféticos

Ecl 12,1-8, perícope sobre a qual se concentrou o objeto de estudo da presente pesquisa, consiste em uma poesia hebraica, caracterizada como uma instrução sapiencial, que tem como temas principais duas realidades do ocaso da vida: a velhice e a morte. Essa perícope integra as seções de conteúdo ético do livro, o que fica evidenciado por meio do imperativo "e lembra-te" (רכזָז) em Ecl 12,1a. Como unidade textual bem delimitada, com excelente nível de coesão e coerência, a perícope está estruturada em quatro partes, enquadradas por uma introdução e uma conclusão, e desenvolvida a partir das locuções de caráter temporal "enquanto não" (אוֹיַּב ש.- Ecl 12,3a). Com acentuada linguagem simbólica, o sábio Qohelet dirige-se ao jovem (רוָָּּ), exortando-o à lembrança dos seus "criadores", isto é, de Deus (v.1a), antes que cheguem a velhice (vv.3-5e) e a morte (vv.5f-7). O tema da morte é relevante e iterado ao longo do livro de Eclesiastes, pois entra em sintonia com a descoberta fundamental de Qohelet: o caráter transitório, expresso pelo vocábulo לֶֶֶ, de todas as realizações humanas e do próprio ser humano. Ao colocar Deus no inicio e no fim do poema ( $\mathrm{Ecl} 12,1.7)$, e ao exortar o jovem à lembrança de Deus antes da velhice e da morte, Qohelet indica que Deus não é marcado pela realidade do לְֶֶ, e quer provocar no jovem discípulo, destinatário da mensagem de seu poema, a reflexão sobre a importância da consciência da transitoriedade da vida e de Deus como único ponto de apoio absoluto.

Palavras-chave: Livro de Eclesiastes. Exegese. Morte. 